\title{
Saving feral horse populations: does it really matter? A case study of wild horses from Doñana National Park in southern Spain
}

\author{
J. L. Vega-Pla ${ }^{\star}$, J. Calderón ${ }^{\dagger}$, P. P. Rodríguez-Gallardo*, A. M. Martinez ${ }^{\ddagger}$ and C. Rico ${ }^{\dagger}$ \\ *Laboratorio de Genética Molecular, Servicio de Cría Caballar y Remonta, Apartado Oficial Sucursal 2, 14071 Córdoba, Spain. †Estación \\ Biológica de Doñana, Av. María Luisa s/n, Pabellón del Perú, 41013 Sevilla, Spain. ${ }^{\ddagger}$ Departamento de Genética, Universidad de Córdoba, \\ Edificio Gregor Mendel, Campus de Rabanales s/n, 14071 Córdoba, Spain
}

\section{Summary}

\begin{abstract}
In the 1980s, a conservation programme involving a feral horse population, the Retuertas horses from the Guadalquivir marshes, was started in the Doñana National Park. The analysis of an extensive genetic survey of this population, which now numbers 100 animals, and 10 additional European and North African breeds using DNA polymorphisms from 22 microsatellites is presented. Highly significant fixation indexes were obtained for all pairwise comparisons between the Retuertas population and other breeds. A population neighbour-joining breed phenogram was built using different distance measures, but the Retuertas population failed to cluster with either of the two major clades of European and North African breeds, highlighting its uniqueness. In fact, the Retuertas population was positioned at the base of the trees, which were rooted using donkey samples. Furthermore, assignment tests and the individual Q-matrices obtained with the STRUCTURE programme isolated the Retuertas breed from the other breeds with only four K groups. Interestingly, some local semi-feral horses, known as Marismeñ o, also currently living in the Guadalquivir marshes, have some microsatellite genotypes that fall well within the Retuertas cluster. This raises the possibility of incorporating horses from the Marismeño population in a future conservation programme.
\end{abstract}

Keywords biochemical polymorphisms, correspondence analysis, genetic distance, horse, microsatellite, phylogeny.

\section{Introduction}

It is not known how long the Doñana feral horses known as Retuertas have lived in an area covering approximately $300 \mathrm{~km}^{2}$ in the Doñana National Park (PND) in southern Spain, but oral and written accounts speculate that they have been in the Guadalquivir marshes since recorded history (Muñ oz-Bort 2004). However, it is widely accepted that ancient wild horse populations almost disappeared from the North Iberian Peninsula and Europe during the Mesolithic period and were not reintroduced to the North of Iberia until the 8th century BC as a domestic animal (Cañon et al. 2000). There are no written records about the origin of the

\section{Address for correspondence}

J. L. Vega-Pla, Laboratorio de Genética Molecular, Servicio de Cría Caballar y Remonta, Apartado Oficial Sucursal 2, 14071-Córdoba, Spain.

E-mail: jvegpla@oc.mde.es

Accepted for publication 7 September 2006
Retuertas, and little is known from a scientific point of view about wild horse populations in southern Spain.

In the 1980s, a programme of conservation of this feral horse population in the Doñana National Park was started. They grazed in the Guadalquivir marshes among a semiferal horse population, known as Marismeñ os, which has traditionally been managed by local farmers who have systematically avoided crosses of feral Retuertas stallions with Marismeñ o mares. It is not known if the horses that were rescued for conservation by scientists on the Doñana Biological Reserve (RBD) look like those that grazed in southern Spain years ago. The morphological and functional features of Retuertas (e.g. an average height of only $1.42 \mathrm{~m}$ and adaptability to hostile marsh environment) are very different from Spanish Pure Breed, Arabian and other Iberian horses of Celtic origin, suggesting genetic isolation of the Retuertas horse population. These circumstances prompted us to compare the Retuertas horse population with the breeds cited above, including Marismeñ os.

Microsatellite markers are nowadays widely used to quantify genetic variation within and among horse breeds 
and to assign individuals to reference populations (Cañon et al. 2000; Glowatzki-Mullis et al. 2005). Therefore, we compared 22 microsatellite loci in the Retuertas horses and other Iberian, European and North African populations.

\section{Materials and methods}

\section{Sample collection}

Fresh blood samples of 55 Retuertas horses (RET) were obtained from the nucleus of the herd in the Doñana Biological Reserve. Blood and hair samples from an additional 449 horses were collected from 11 breeds, including Spanish Pure Breed (SPB, 60; also known as Andalusian Horse), Thoroughbred (THB, 46), Arabian (ARB, 48), Losino (LOS, 58), Asturcón (AST, 39), Mallorquín (MAL, 30), Menorquín (MEN, 69), Potok (POT, 27), Spanish Trotter (TRO, 46) and Marismeño (MAR, 26). Donkey samples (Equus asinus) (DNK, 44) were collected as an outgroup.

\section{Serum protein and microsatellite typing}

Five serum proteins (A1B-glycoprotein, albumin, carboxilesterase, vitamin D-binding protein and transferrin) were typed on the horse samples using one-dimensional PAGE according to Gahne et al. (1977). Following whole DNA preparation, samples were PCR amplified for 22 microsatellite loci: AHT4, AHT5 (Binns et al. 1995), ASB2, ASB17 (Breen et al. 1997), ASB23 (Lear et al. 1999), HMS3, HMS6, HMS7 (Guérin et al. 1994), HTG4 (Ellegren et al. 1992), HTG10 (Marklund et al. 1994), LEX33 (Shiue et al. 1999), TKY279, TKY287, TKY294, TKY297, TKY301, TKY312, TKY321, TKY325, TKY333, TKY337 and TKY341 (Tozaky et al. 2001). Sizing of PCR products was accomplished using an internal size standard and a reference sample on each gel.

\section{Data analysis}

FSTAT v2.9.3.2 (Goudet 1995) was used to calculate fixation indexes, allele numbers, and observed and expected heterozygosities. Levels of breed differentiation were estimated by calculating $\mathrm{F}_{\mathrm{ST}}$ across breeds. Within-breed diversity (donkey excluded) was investigated by calculating allele number, observed and unbiased expected estimates of gene diversity within breeds (Nei 1973) and their standard deviations using Excel Microsatellite Toolkit software (Park 2001). Distribution of gene variability within and between breeds was studied by analysing Wright's (1951) F-statistics (Weir \& Cockerham 1984; Excoffier et al. 1992) as implemented in GENETIX v4.04 (http://www.univ-montp2.fr/ -ge netix/genetix/genetix.htm). The inbreeding coefficient $\left(\mathrm{F}_{\mathrm{IS}}\right)$ across populations was calculated with a 95\% confidence interval determined using 1000 permutations and 10000 bootstraps across loci.
Samples were tested for linkage disequilibria and departures from Hardy-Weinberg equilibrium by the Markov chain method. Heterogeneity in genotype distribution for all loci and all pairwise comparisons was tested based on an assumption of no differentiation, and it was implemented in GENEPOP v3.4 (Raymond \& Rousset 1995).

Because drift and mutation influence differences between populations with long-term reproductive isolation, and because populations of recent divergence are probably mostly influenced by drift (Slatkin 1995), we followed two approaches in investigating the amplitude of genetic differentiation between breeds. Firstly, the computer program ARLEQUIN 3.01 (http://lgb.unige.ch/arlequin/) was used to calculate pairwise fixation indices based on allele frequency variation using an AMOva framework to estimate weighted $\mathrm{F}_{\mathrm{ST}}$ statistics (h) over all loci. Secondly, we calculated $\mathrm{q}$ (an $\mathrm{R}_{\mathrm{ST}}$ analog), which is based on the stepwise mutation model (SMM) and takes into account differences in sample size and differences in variance between loci using $\mathrm{R}_{\mathrm{ST}} \mathrm{CALC}$ (Goodman 1997). The significance of genetic subdivision was assessed using 1000 permutations in both ARLEQUIN and $\mathrm{R}_{\mathrm{ST}} \mathrm{CALC}$. To correct for multiple simultaneous comparisons, sequential Bonferroni corrections were applied to all pairwise tests using a global significance level of 0.05 (Rice 1989).

Genetic divergence among breeds was estimated by two approaches because of debate on model-specific distance estimators for microsatellite loci (e.g. Takezaki \& Nei 1996; Goodman 1997; Angers \& Bernatchez 1998). We first quantified Cavalli-Sforza \& Edwards' (1967) chord distance $\left(\mathrm{D}_{\mathrm{CE}}\right.$ ) and Nei's distance $\mathrm{D}_{\mathrm{A}}$ (Nei 1983) using Genedist. We also calculated Goldstein et al.'s (1995) delta-mu squared $(d \mathbf{l})^{2}$ pairwise distances using $\mathrm{R}_{\mathrm{ST}} \mathrm{CALC}$ (Goodman 1997). Phenograms based on Cavalli-Sforza and Edwards' distance $\left(D_{C E}\right)$, Nei's distance $\left(D_{A}\right)$ and delta-mu squared $(d \mathbf{l})^{2}$ were constructed using the NEIGHBOR programme with the neighbor-joining algorithm (Saitou \& Nei 1987). An additional phenogram was estimated using a maximum likelihood algorithm (CONTML). Support for the tree nodes was assessed by 10000 bootstraps of gene frequencies using the SEQBOOT programme and compiled using the CONSENSE programme. All these programmes are included in the PHYLIP computer package, version 3.57c (Felsenstein 1995). Furthermore, the structure v.2.1 computer program (Pritchard et al. 2000) was used to calculate clustering at different $\mathrm{K}$ values, which is the number of assumed populations using the admixture model in which an individual may have mixed ancestry. It is based on a Bayesian clustering algorithm that uses multilocus genotypes to infer population structure and to assign individuals to populations. We performed runs of $10^{6}$ iterations, following a burn-in period of 100000 iterations. To determine the adequate number of inferred clusters to fit the data, we evaluated K-values from 2 to 14 and ran three independent simulations of this length for each $\mathrm{K}$ to evaluate stability. Graphics from 
these results were drawn using DISTRUCT software (http:// rosenberglab.bioinformatics.med.umich.edu/distruct.html).

Factorial correspondence analysis (Lebart et al. 1984) was performed to test for possible admixture between the Retuertas and other populations using the module 'AFD sub populations' of the GENETIX v4.04 software. This method does not depend on the mutation model used for markers (Laloe et al. 2002), which is advantageous for analysis of microsatellites because knowledge of their mutation process is insufficient (Estoup \& Cornuet 1999). Concordance among different methods to study the genetic differentiation between individuals or populations highlights the robustness of the results (MacHugh et al. 1997).

\section{Results}

\section{Protein polymorphisms}

Of the five protein systems analysed, A1B-glycoprotein, albumin, vitamin D-binding and transferrin showed usual electrophoretic variants. However, the Retuertas population showed a carboxilesterase allele that has not previously been recorded for any horse blood typing lab in any horse comparison test organized by the International Society for Animal Genetics (ISAG). The new allele, provisionally named $\mathrm{m}$, occurs in this population at a frequency of 0.16 .

\section{Microsatellite diversity and test of disequilibria}

All microsatellite markers showed high levels of polymorphism, with an average of 10.95 alleles per locus, and all breeds compared were genetically diverse, showing high heterozygosities at most loci (Table S1). A mean of 7.07 alleles per population were detected; the Retuertas and
Thoroughbred populations showed the lowest number of alleles (5.91 and 5.93 respectively). Observed and expected heterozygosities in each breed and their respective standard errors are shown in Table 1 . Gene diversity indicated that, despite selective breeding programmes for most of these breeds, levels of heterozygosity remain similar to those reported in other populations of large wild herbivorous mammals (e.g. Polziehn et al. 2000; Bonnet et al. 2002). The sample of Arabian horses (ARA) showed a significant deficiency of heterozygosity. In contrast, the Retuertas (RET) population showed a significant excess of heterozygosity and the lowest $F_{\text {IS }}$ value. Negative $F_{\text {IS }}$ values were also found in other endangered breeds, but these values were not significant. Furthermore, only 13 significant departures from Hardy-Weinberg equilibrium were detected among 242 population-locus combinations, precisely the number expected by chance at the $5 \%$ level. No population showed more than three markers deviating from Hardy-Weinberg equilibrium.

\section{Breed differentiation and genetic distances}

The average F-statistics and their 95\% confidence intervals obtained with 10000 bootstraps over loci were $F_{\text {IS }} 1 / 4$ )0.008 ()0.0208-0.0048), F $_{\text {IT }} 1 / 40.0848$ (0.072-0.097) and $F_{\mathrm{ST}} 1 / 40.091$ (0.084-0.099). However, all comparisons between pairs of breeds gave fixation indices significantly different from zero, irrespective of whether the index was based on the infinite alleles model (h) or the stepwise mutation model (q) (Table 2). Although not fully resolved, dendrograms depicted four clusters of closely related breeds with bootstrap support above 50\%, irrespective of whether they were based on the maximum likelihood or NeighbourJoining algorithms using chord distance $\left(D_{C E}\right)$ or Nei's
Table 1 Sample sizes, number of alleles, hetrozygosities and inbreeding coefficients.

\begin{tabular}{|c|c|c|c|c|c|}
\hline Breed $^{1}$ & $\begin{array}{l}\text { Sample } \\
\text { size }\end{array}$ & No. alleles (SD) & $\begin{array}{l}\text { Unbiased } \\
\text { heterozygosity } \\
\text { (SD) }\end{array}$ & $\begin{array}{l}\text { Observed } \\
\text { heterozygosity } \\
\text { (SD) }\end{array}$ & $\begin{array}{l}\text { Inbreeding } \\
\text { coefficient }\left(F_{\mid S}\right)\end{array}$ \\
\hline RET & 55 & $5.91(1.06)$ & $0.6857(0.0194)$ & $0.7255(0.0129)$ & )0.0587* \\
\hline ARA & 48 & $6.05(1.50)$ & $0.6725(0.0245)$ & $0.6353(0.0148)$ & $0.0559 *$ \\
\hline AST & 39 & $7.18(1.74)$ & $0.7361(0.0195)$ & $0.7584(0.0146)$ & ) 0.0307 \\
\hline SPB & 60 & 7.77 (1.34) & $0.7522(0.0171)$ & $0.7477(0.0120)$ & 0.0060 \\
\hline THB & 46 & $5.73(1.08)$ & $0.7350(0.0128)$ & $0.7418(0.0138)$ & 0.0093 \\
\hline LOS & 59 & $8.27(1.52)$ & $0.7444(0.0169)$ & $0.7522(0.0120)$ & 0.0105 \\
\hline MAL & 30 & $6.50(1.26)$ & $0.7354(0.0212)$ & $0.7583(0.0167)$ & 0.0318 \\
\hline MAR & 26 & $7.68(1.25)$ & $0.7951(0.0087)$ & $0.7863(0.0172)$ & 0.0113 \\
\hline MEN & 69 & $7.50(1.65)$ & $0.7450(0.0163)$ & $0.7483(0.0114)$ & 0.0014 \\
\hline РОТ & 29 & $7.86(2.12)$ & $0.7777(0.0261)$ & $0.7815(0.0168)$ & 0.0049 \\
\hline TRO & 46 & 7.27 (1.08) & $0.7593(0.0145)$ & $0.7520(0.0136)$ & 0.0097 \\
\hline
\end{tabular}

SD, standard deviation; * Significant values for heterozygous deficit or excess $(P<0.05)$ ${ }^{1}$ Breed abbreviations: RET, Retuertas; ARA, Arabian; AST, Asturcón; SPB, Spanish Pure Breed (also known as Andalusian Horse); THB, Thoroughbred; LOS, Losino; MAL, Mallorquín; MAR, Marismeño; MEN, Menorquín; POT, Potok; TRO, Spanish Trotter. 
Table 2 Pairwise fixation indices for all horse breed pairs and donkeys.

\begin{tabular}{lllllllllllll}
\hline Breed $^{1}$ & RET & ARA & AST & SPB & THB & LOS & MAL & MAR & MEN & POT & TRO & DNK \\
\hline RET & & 0.149 & 0.113 & 0.091 & 0.160 & 0.108 & 0.122 & 0.068 & 0.117 & 0.110 & 0.190 & 0.345 \\
ARA & 0.161 & & 0.082 & 0.101 & 0.124 & 0.086 & 0.102 & 0.066 & 0.051 & 0.063 & 0.087 & 0.788 \\
AST & 0.166 & 0.109 & & 0.109 & 0.189 & 0.039 & 0.101 & 0.080 & 0.039 & 0.052 & 0.118 & 0.334 \\
SPB & 0.106 & 0.108 & 0.079 & & 0.103 & 0.066 & 0.078 & 0.021 & 0.030 & 0.090 & 0.134 & 0.314 \\
THB & 0.181 & 0.134 & 0.122 & 0.095 & & 0.137 & 0.116 & 0.076 & 0.127 & 0.127 & 0.066 & 0.337 \\
LOS & 0.160 & 0.113 & 0.059 & 0.067 & 0.118 & & 0.071 & 0.080 & 0.001 & 0.048 & 0.082 & 0.318 \\
MAL & 0.156 & 0.127 & 0.087 & 0.076 & 0.117 & 0.088 & & 0.055 & 0.074 & 0.087 & 0.110 & 0.352 \\
MAR & 0.070 & 0.078 & 0.047 & 0.015 & 0.068 & 0.044 & 0.056 & & 0.059 & 0.045 & 0.098 & 0.313 \\
MEN & 0.146 & 0.118 & 0.079 & 0.063 & 0.119 & 0.070 & 0.066 & 0.050 & & 0.059 & 0.077 & 0.320 \\
POT & 0.160 & 0.118 & 0.062 & 0.062 & 0.092 & 0.040 & 0.072 & 0.039 & 0.071 & 0.079 \\
TRO & 0.127 & 0.113 & 0.087 & 0.074 & 0.072 & 0.084 & 0.080 & 0.051 & 0.082 & 0.058 & 0.074 & 0.332 \\
DNK & 0.790 & 0.379 & 0.769 & 0.782 & 0.775 & 0.775 & 0.787 & 0.743 & 0.770 & 0.742 & 0.756 & 0.328 \\
\hline
\end{tabular}

Fixation indices were computed following the infinite allele model (h; lower diagonal), and the unbiased estimator of Slatkin's RST (q; Goodman 1997; upper diagonal).

${ }^{1}$ Breed abbreviations: RET, Retuertas; ARA, Arabian; AST, Asturcón; SPB, Spanish Pure Breed (also known as Andalusian Horse); THB, Thoroughbred; LOS, Losino; MAL, Mallorquín; MAR, Marismeño; MEN, Menorquín; POT, Potok; TRO, Spanish Trotter; DNK, Donkey.

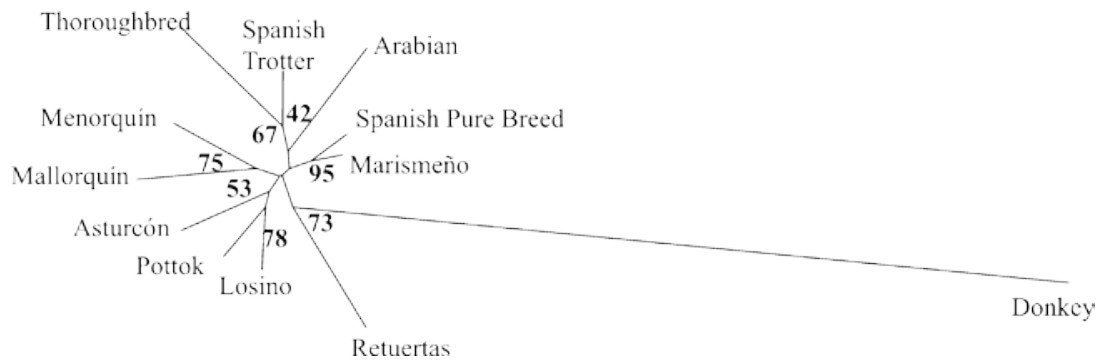

Figure 1 Neighbour-joining tree built from $D_{A}$ distances of eleven horse populations including a sample of donkey to root the tree. Numbers indicate percentage of 1000 bootstrap replications across loci. distance (Da). Thus, only Nei's (Da) distance is presented (Fig. 1). Interestingly, the Retuertas population did not cluster with any of these European breeds and fell in a dichotomy with the outgroup, with bootstrap support above $70 \%$. One cluster grouped Atlantic breeds of Celtic origin (Asturcón, Potok and Losino) and another of Mediterranean breeds of the same origin (Menorquín and Mallorquín). Bootstrap support varied from $42 \%$ to $78 \%$ for the internal nodes within this first main cluster. The smallest distance was between the Marismeñ o population and Spanish Pure Breed. This is not surprising as the Marismeñ o has traditionally been crossbred with Spanish Pure Breed stallions, and the Marismeño population is closely related to the Spanish Pure Breed horse. Bootstrap support for this cluster was 95\%. Spanish Trotter showed an expected relationship with Thoroughbred. The Retuertas population did not cluster with either of these four major clades, and its location is alone near the root with relatively high bootstrap support, which further substantiates the uniqueness of these horses.

The STRUCTURE programmes showed that the independent runs from $K^{1 / 4} 2$ to $K^{1 / 4} 14$ produced consistent results. Clustering was performed on the entire data set with increasing numbers of inferred clusters. The assignment test results determined that 12 breeds best fit the data and that the Losino and Pottok horses appear admixed. A plot of the clustering results for the individuals in the sample is shown in Fig. 2. K $1 / 42$ indicated the presence of two very distinct clusters, corresponding to the donkey and horses. From sample $K 1 / 44-12$, assignments reflected the presence of population structure associated with progressive genetic differentiation (e.g. autochthonous Spanish breeds versus international breeds, Celtic ponies versus Mediterranean breeds, etc.). Assignment tests isolated the Retuertas horse from the other breeds as early as four $\mathrm{K}$ groups, and this group maintained its integrity throughout the analysis. It was clearly differentiated from its neighbour, the Marismeño, and all other Spanish breeds.

\section{Factorial correspondence analysis}

Correspondence analysis was further used to detect admixtures between the Retuertas and the rest of the populations (Fig. 3). The first axis accounted for $19.93 \%$ of the total inertia proportion, while the second axis accounted for $17.05 \%$. This analysis also placed the Retuertas horses in a cluster, thereby further substantiating its singularity. 
Figure 2 Graphs of individual Q-matrices obtained with STRUCTURE programme for $\mathrm{K}^{1 / 4}$ 2-12. Individuals were ordered by populations and separators between them were included.
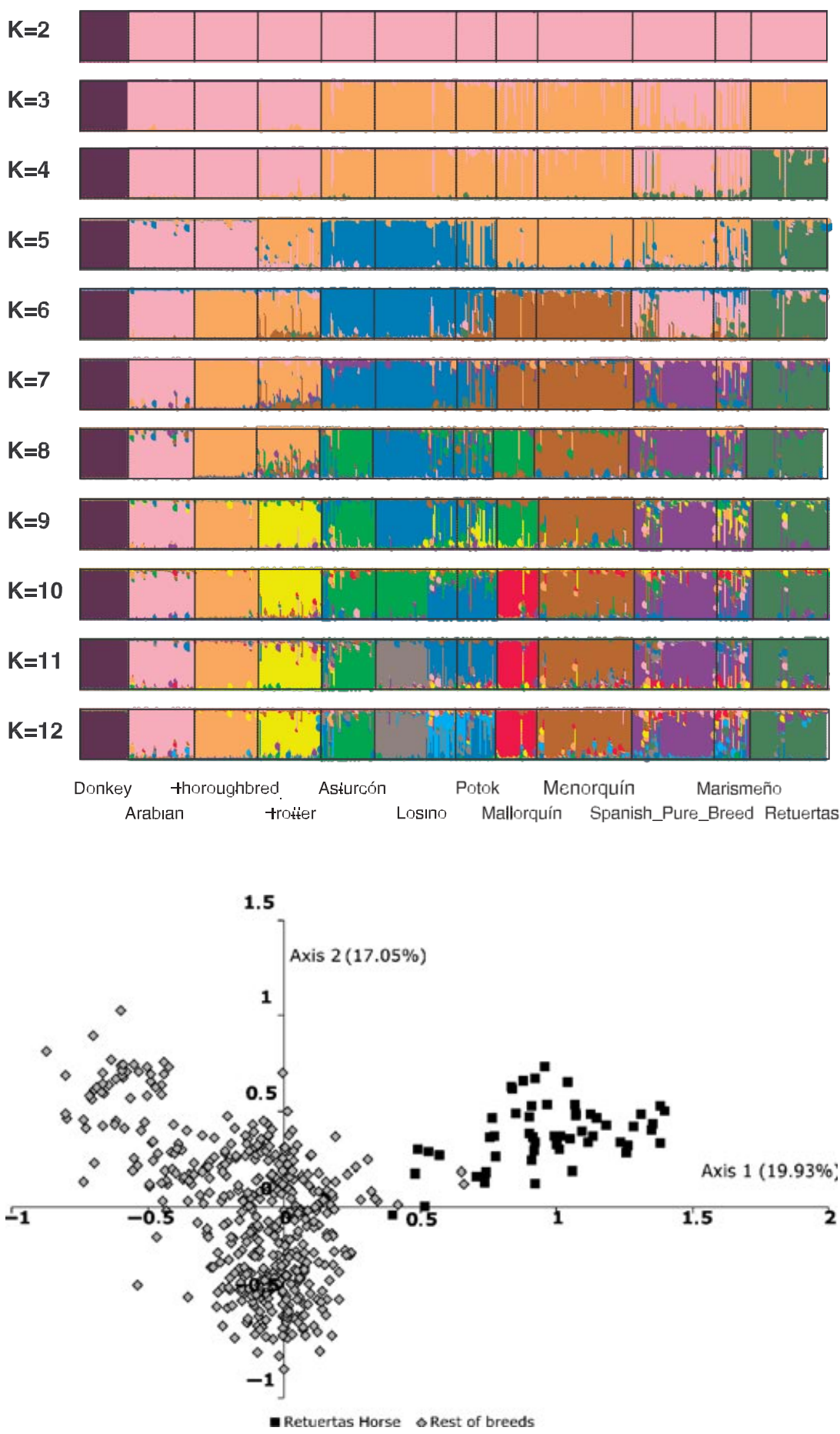

mutation in this isolated gene pool. The latter possibility is remote because the average nucleotide substitution rate for non-synonymous sites is $0.74 \pm 0.67$ per site per $10^{9}$ years. Even in the most variable genes so far characterized, such as MHC genes, the nucleotide substitution rate at non-synonymous sites was only $3.06 \pm 0.37$ per site per $10^{9}$ years (Graur \& Li 1999). However, confirmation of these hypotheses requires further testing. modern breeds so far characterised, or represents a new 
The observed levels of differentiation among the horse breeds are low when compared with other domestic species (e.g. Hanslik et al. 2000; Martínez et al. 2000), but similar to those obtained in other horse studies (Bjørnstad et al. 2000; Cañon et al. 2000; Bjørnstad \& Røed 2002; Aberle et al. 2004; Glowatzki-Mullis et al. 2005) and higher than those obtained by Aranguren-Méndez et al. (2001) in donkeys. Furthermore, levels of genetic diversity are also similar to those obtained in the above horse breed studies. Fixation indices based on the infinite allele model (h) or the stepwise mutation model (q) were of the same order of magnitude. These results indicated that both drift and mutation probably influence the observed levels of divergence. To illustrate how time of divergence affects these estimators, one can refer to the $\mathrm{h}$ and $\mathrm{q}$ pairwise values between horses and donkeys. For h values, they are around $30 \%$, while q values are above $70 \%$, reflecting the thousands of generations of divergence between horses and donkeys. In this case, it is expected that the $\mathrm{q}$ estimator better reflects the magnitude of divergence between species in the absence of gene flow (Slatkin 1995; Balloux \& Goudet 2002).

The relationship analysis provided a rather surprising result. The logically expected outcome of the breed phenogram was that the Retuertas horse would fall close to the Marismeñ o and Spanish Pure Breed, as these populations share a common geographic area and habitat in semi-feral conditions. Therefore, the eventual crossbreeding of these populations would have been possible. However, local horse breeders have systematically avoided crossing their mares and stallions with the feral populations of Retuertas horses, and whenever an accidental crossing has taken place, the foals were taken out of the Marismeño population. This result is well supported by all methods of tree building and, even when poor breed differentiation causing low bootstrap values was observed in many nodes, the Retuertas population showed $73 \%$ of robustness of the node where it was situated.

A further line of evidence for the above arguments is the individual clustering obtained using a Bayesian approach, which indicates that horse breeds that are not outbreed fit well in their own cluster, a result similar to a recent report for Arabians and Thoroughbreds (Glowatzki-Mullis et al. 2005). The Retuertas horses also clustered in a unified population from early runs of the analysis, substantiating its integrity and uniqueness. Interestingly, some horses currently living in the Guadalquivir marshes among Marismeñ o horses have a microsatellite multilocus genotype that falls well within the Retuertas cluster. This raises the possibility of incorporating horses from the Marismeño population in a future conservation programme after extensive morphological and genetic characterization, which will result in an increased effective population size.

These results raise the possibility that the Retuertas horse population has remained reproductively isolated from most domestic breeds for a long time and may well be a direct descendent of wild horses that have survived in the Gualdquivir marshes for centuries. Sequencing and phylogenetic analyses of genes and the control region from mtDNA have shown evidence of multiple events of domestication in the Old World in many distinct geographic areas followed by extensive gene flow leading to incomplete lineage sorting and extensive sharing of haplotypes among breeds (Vila et al. 2001; Hill et al. 2002; Jansen et al. 2002; Bruford et al. 2003). Therefore, analysis of mtDNA of the Retuertas population would result in inconclusive evidence as well.

A last issue raised by these results refers to the longstanding debate on minimum viable population size (e.g. Franklin 1980; Connor \& Simberloff 1986; Lande \& Barrowclough 1987; Walters 1991; Craig 1994). The widely accepted view at present suggests that there is no single number that tips a species into extinction or survival but that a number of demographic, stochastic and genetic variance factors play fundamental roles in the fate of small populations. The present Retuertas horse population shows no signs of inbreeding depression and has recovered from only some tens of horses. Whether this is sufficient to ensure its future survival remains to be seen, but it clearly indicates that because these horses were introduced into a national park and left to live with no human intervention, protecting the natural habitat of a population plays a major impact in its survival.

\section{Acknowledgements}

We are particularly in debt to Diego Lopez and the personnel of the DBR for their help in collecting wild horse samples. We would also like to thank Bartolomé Alcaide and Rafael Jiménez for their technical laboratory support. We also thank A. Green, G.F. Turner and J. Juste for valuable comments on an earlier version of this manuscript. This research was funded by Fondo de Explotación de los Servicios de Cría Caballar y Remonta del Ministerio de Defensa of Spain as part of their efforts to improve the genetic diversity of the Spanish horses.

\section{References}

Aberle K.S., Hamann H., Drögemü ller C. \& Distl O. (2004) Genetic diversity in German draught horse breeds compared with a group of primitive, riding and wild horses by means of microsatellite DNA markers. Animal Genetics 35, 270-7.

Angers B. \& Bernatchez L. (1998) Combined use of SMM and nonSMM methods to infer fine structure and evolutionary history of closely related brook charr (Salvelinus fontinalis, Salmonidae) populations from microsatellites. Molecular Biology and Evolution 15, 143-59.

Aranguren-Méndez J., Jordana J. \& Gomez M. (2001) Genetic diversity in Spanish donkey breeds using microsatellite DNA markers. Genetic Selection Evolution 33, 433-42.

Balloux F. \& Goudet J. (2002) Statistical properties of population differentiation estimators under stepwise mutation in a finite island model. Molecular Ecology 11, 771-83. 
Binns M.M., Holmes N.G., Holliman A. \& Scott A.M. (1995) The identification of polymorphic microsatellite loci in the horse and their use in Thoroughbred parentage testing. British Veterinary Journal 151, 9-15.

Bjørnstad G. \& Røed K.H. (2002) Evaluation of factors affecting individual assignment precision using microsatellite data from horse breeds and simulated breed crosses. Animal Genetics 33, 264-70.

Bjørnstad G., Gunby E. \& Røed K.H. (2000) Genetic structure of Norwegian horse breeds. Journal of Animal Breeding and Genetics 117, 307-17.

Bonnet A., Thévenon S., Maudet F. \& Maillard J.C. (2002) Efficiency of semi-automated fluorescent multiplex PCRs with eleven microsatellite markers for genetic studies of deer populations. Animal Genetics 33, 343-50.

Breen M., Lindgren G., Binns M.M., Norma, J., Irvin, Z., Bell, K., Sandberg, K. \& Ellegren, H. (1997) Genetical and physical assignments of equine microsatellites - first integration of anchored markers in horse genome mapping. Mammalian Genome 8, 26773.

Bruford M.W., Bradley D.G. \& Luikart G. (2003) DNA markers reveal the complexity of livestock domestication. Nature Reviews Genetics 4, 900-10.

Cañon J., Checa M.L., Carleos C., Vega-Pla J.L., Vallejo M. \& Dunner S. (2000) The genetic structure of Spanish Celtic horse breeds inferred from microsatellite data. Animal Genetics 31, 39-48.

Cavalli-Sforza L.L. \& Edwards A.W.F. (1967) Phylogenetic analysis: models and estimation procedures. American Journal of Human Genetics 19, 233-57.

Connor E. \& Simberloff D. (1986) Competition, scientific method, and null hypotheses in ecology. American Scientist 74, 155-62.

Craig J.L. (1994) Metapopulations: is management as flexible in nature? In: Creative Conservation: Interactive Management of Wild and Captive Animals. (Ed. by P.J.S. Olney, G.M. Mace \& A.T.C. Feister ), pp. 50-66. Chapman and Hall, London.

Ellegren H., Johansson M., Sandberg K. \& Andersson L. (1992) Cloning of highly polymorphic microsatellites in horse. Animal Genetics 23, 133-42.

Estoup A. \& Cornuet J.M. (1999) Microsatellite evolution: inferences from population data. In: Microsatellites, Evolution and Applications. (Ed. by D.B. Goldstein \& C. Schlotterer ), pp. 49-65. Oxford University Press, Oxford.

Excoffier L., Smouse P.E. \& Quattro J.M. (1992) Analysis of molecular variance inferred from metric distances among DNA haplotypes: application to human mitochondrial DNA restriction data. Genetics 131, 479-91.

Felsenstein J. (1995). PHYLIP (Phylogeny Inference Package). Version 3.57. University of Washington, Seattle.

Franklin I.R. (1980) Evolutionary change in small populations. In: Conservation Biology, an Evolutionary-Ecological Perspective. (Ed. by M.E. Soule \& B.A. Wilcox ), pp. 75-120. Sinauer Associates, Sunderland.

Gahne B., Juneja R.K. \& Grolmus J. (1977) Horizontal polyacrylamide gradient gel eletrophoresis for the simultaneous phenotyping of transferrin, post-transferrin, albumin and postalbumin in the blood plasma of cattle. Animal Blood Groups and Biochemical Genetics 8, 127-37.

Glowatzki-Mullis M.L., Muntwyler J., Pfister W., Marti E., Rieder S. Poncet P.A. \& Gaillard C. (2005) Genetic diversity among horse populations with a special focus on the Franches-Montagnes breed. Animal Genetics 37, 33-9.

Goldstein D.B., Linares A.R., Cavalli-Sforza L.L. \& Feldman M.W. (1995) An evaluation of genetic distances for use with microsatellite loci. Genetics 139, 463-71.

Goodman S.J. (1997) Rst Calc: a collection of computer programs for calculating estimates of genetic differentiation from microsatellite data and determining their significance. Molecular Ecology 6, 881-5.

Goudet J. (1995) FSTAT Version 1.2: a computer program to calculate F-statistics. Journal of Heredity 86, 178-9.

Graur D. \& Li W.H. (1999) Rates and pattems of molecular substitution. In: Fundamentals of molecular evolution. (Ed. by D. Graur \& W.H. Li ), pp. 100-15. Sinauer Associates, Sunderland.

Guérin G., Bertand M. \& Amigues Y. (1994) Characterisation of seven new horse microsatellites: HMS1, HMS2, HMS3, HMS5, HMS6, HMS7, HMS8. Animal Genetics 25, 62.

Hanslik S., Harr B., Brem G. \& Scholötterer C. (2000) Microsatellite analysis reveals substantial genetic differentiation between contemporary New World and Old World Holstein Friesian populations. Animal Genetics 31, 31-8.

Hill E.W., Bradley D.G., Al-Barody M., Ertugrul O., Splan R.K., Zakharov I. \& Cunningham E.P. (2002) History and integrity of thoroughbred dam lines revealed in equine mtDNA variation. Animal Genetics 33, 287-94.

Jansen T., Foster P., Levine M.A., Oelke H., Hurles M., Renfrew C., Weber J. \& Olek K. (2002) Mitochondrial DNA and the origins of domestic horse. Proceedings of the National Academy of Sciences of the United States of America 99, 10905-10.

Laloe D., Moazami-Goudarzi K. \& Chessel D. (2002) Contribution of Individual Markers to the Analysis of the Relationships among Breeds by Correspondence Analysis. Communication $N^{\circ} 26-06$ of the 7th World Congress on Genetics Applied to Livestock Production, August 19-23, Montpellier, France.

Lande R. \& Barrowclough G.F. (1987) Effective population size, genetic variation and their use in population management. In: Viable Populations for Conservation (Ed. by M.E. Soulé ), pp. 87123. Cambridge University Press, Cambridge.

Lear T.L., Brandon R. \& Bell K. (1999) Physical mapping of ten equine dinucleotide repeat microsatellites. Animal Genetics 30, 235.

Lebart L., Morineau A. \& Warwick K. (1984) Multivariante Descriptive Statistical Analysis. John Wiley and Sons, New York.

MacHugh D.E., Shriver L.D., Loftus R.T., Cunningham P. \& Bradley D.G. (1997) Microsatellite DNA variation and the evolution, domestication and phylogeography of taurine and zebu cattle. Genetics 146, 1071-86.

Marklund S., Ellegren H., Eriksson S., Sandberg K. \& Andersson L. (1994) Parentage testing and linkage analysis in the horse using a set of highly polymorphic microsatellites. Animal Genetics, 25, 19-23.

Martínez A.M., Delgado J.V., Rodero A. \& Vega-Pla J.L. (2000) Genetic structure of the Iberian pig breed using microsatellites. Animal Genetics 31, 295-301.

Muñ oz-Bort D. (2004) Introducció n. In: La Ganadería Caballar en la Villa de Almonte. (Ed. by A de Almonte), pp. 21-3. Artes Gráficas Impresol, Almonte.

Nei M. (1973) Analysis of gene diversity in subdivided populations. Proceedings of the National Academy of Sciences of the United States of America 70, 3321-3. 
Nei M. (1983) Genetic polymorphism and the role of mutation in evolution. In: Evolution of Genes and Proteins (Ed. by M. Nei \& R. Khoen ), pp. 165-90, Sinauer Associates: Sunderland.

Park S.D.E. (2001) Trypanotolerance in West African Cattle and the Population Genetic Effects of Selection. PhD Thesis. University of Dublin.

Polziehn R.O., Hamr J., Mallory F.F. \& Strobeck C. (2000) Microsatellite analysis of North American wapiti (Cervus elaphus) populations. Molecular Ecology 9, 1561-76.

Pritchard J.K., Stephens M. \& Donnelly P. (2000) Inference of population structure using multilocus genotype data. Genetics 155 , 945-59.

Raymond M. \& Rousset F. (1995) GENEPOP (version 1.2): population genetics software for exact tests and ecumenicism. Journal of Heredity 86, 248-9.

Rice W.R. (1989) Analyzing tables of statistical tests. Evolution 43, 223-5.

Saitou N. \& Nei M. (1987) The neighbor-joining method: a new method for reconstructing phylogenetic trees. Molecular Biology and Ecology 4, 406-25.

Shiue Y.L., Bickel L.A., Caetano A.R. et al. (1999) A synteny map of the horse genome comprised of 240 microsatellite and RAPD markers. Animal Genetics 30, 1-9.

Slatkin M. (1995) A measure of population subdivision based on microsatellite allele frequencies. Genetics 139, 457-62.

Takezaki N. \& Nei M. (1996) Genetic distances and reconstruction of phylogenetic trees from microsatellite DNA. Genetics 144, 38999.
Tozaky T., Kakoi H., Mashima S. Hirota K., Hasgawa T., Ishida N., Miura N., Choi-Miura N. \& Tomita M. (2001) Population study and validation of paternity testing for Thoroughbred horses by 15 microsatellite loci. Journal of Veterinary Medical Sciences 63, 1191-7.

Walters J.R. (1991) Application of ecological principles to the management of endangered species: the case of the Red-cockaded Woodpecker. Annual Review of Ecology and Systematics 22, 50523.

Weir B.S. \& Cockerham C.C. (1984) Estimating F-statistics for the analysis of population structure. Evolution 38, 1358-70.

Wright S. (1951) The genetical structure of populations. Annals of Eugenics 15, 323-54.

\section{Supplementary Material}

The following supplementary material is available for this article online from http://www.blackwell-synergy.com/doi/ full/10.1111/j.1365-2052.2006.01533.x

Table S1 Number of alleles, unbiased heterozygosity, observed heterocygosity, genetic differentiation index $\left(\mathrm{F}_{\mathrm{ST}}\right)$ and inbreeding coefficient $\left(\mathrm{F}_{\mathrm{IS}}\right)$.

Please note: Blackwell Publishing is not responsible for the content or functionality of any supplementary materials supplied by the authors. 